\title{
Dentin Bond Strength and Reliability of Experimental Bioactive Composites
}

\author{
Josipa Vukelja ${ }^{1}$, Matej Par $^{2}$, Zrinka Tarle ${ }^{2}$ (D) , Eva Klarić Sever ${ }^{2}$ \\ ${ }^{1}$ Community Health Centre Donja Zdenčina \\ ${ }^{2}$ Department of Endodontics and Restorative Dentistry, School of Dental Medicine University of Zagreb
}

OPEN ACCESS

Correspondence: prof.dr. sc. Zrinka Tarle tarle@sfzg.hr orcid.org/0000-0001-7096-4575

This article was submitted to RAD CASA - Medical Sciences as the original article

Conflict of Interest Statement: The authors declare that the research was conducted in the absence of any was cond com conflict of interest.

Received: 20 February 2020 Accepted: 28 May 2020 Published: 20 June 2020

Citation:

Vukelja J, Par M, Tarle Y, Klarić Sever E. Dentin bond strength and reliability of experimental bioactive composites. RAD CASA - Medical Sciences. $543=50-51(2020): 11-16$ DOI: https://dx.doi.org/10.21857/ yl4okflxz9

Copyright (C) 2020 Vukelja J, Par M, Tarle Y, Klarić Sever E. This is an Men-access article distributed under the -access article distributed under the terms of the Creative Commons Attribution License (CC BY). The use, forums is permittuction in other forums is permitted, provided the original author(s) and the copyright owners(s) are credited and that the original publication in this journal is cited, in accordance whit accepted adacemic practice. No use, distribution or reproduction is permitted which does not comply with these terms.

\section{ABSTRACT:}

Weibull analysis of bond strength

AIM: To compare differences in outcomes of statistical approaches of reliability analysis (Weibull) and conventional statistics for bond strength of experimental remineralizing composites and disclose changes that would not be discernible by using just one statistical approach.

Materials AND Methods: Experimental composites were made by blending a Bis-GMA/TEGDMA resin with bioactive glass (BG) and inert fillers (barium glass and silica) in a centrifugal mixer. Inert fillers were admixed to the total filler load of $70 \mathrm{wt} \%$. Control composite incorporated only inert fillers (70 wt $\%$ ). Two remineralizing composites with 10 or $40 \mathrm{wt} \%$ of BG were marked as bioactive- 10 and bioactive- 40 . Dentin substrates were prepared from intact third molars, polished under the water using P600 silicon carbide paper and embedded into an acrylic resin. Composite cylinders ( $\mathrm{d}=3 \mathrm{~mm}, \mathrm{~h}=2 \mathrm{~mm})$ were bonded on dentin substrates using a two-step self-etch bonding agent (Clearfil SE Bond 2, Kuraray). Specimens were stored at $37^{\circ} \mathrm{C}$ in distilled water and fractured in shear mode after 1 week and 1 year. Per experimental group 20 samples were prepared in order to obtain the optimal sample size for Weibull analysis (total $\mathrm{n}=120$ for the whole study).

RESULTS: Mean bond strengths measured after 1 week and 1 year were statistically similar for the control composite (21.9 vs. $24.0 \mathrm{MPa}$ ) and for bioactive-10 (19.6 vs. 19.1 MPa). Nevertheless, Weibull statistics identified a significant decrease in bond reliability after aging: Weibull moduli were decreased from 13.5 to 3.9 for the control composite and from 12.3 to 3.8 for bioactive-10. For bioactive- 40 , mean bond strength declined significantly after 1 year $(8.1 \mathrm{vs.} 6.8 \mathrm{MPa})$ but its reliability remained unchanged, as identified by statistically similar Weibull moduli.

Conclusions: A decrease in dentin bond strength after 1 year was identified using Weibull analysis in the control and experimental bioactive composite, while conventional statistics were incapable to distinguish changes in mean bond strength.

KEYWORDS: dentin bond strength, Weibull analysis, reliability, bioactive glass 45S5, shear bond strength adhesives, dental materials, composite resins

\section{SAŽETAK:}

SNAGA SVEZIVANJA NA DENTIN I POUZDANOST EKSPERIMENTALNIH BIOAKTIVNIH KOMPOZITA

Cilj: Usporediti razlike u rezultatima snage svezivanja eksperimentalnih remineralizacijskih kompozita dobivenih statističkim pristupom analize pouzdanosti (Weibull) i konvencionalne statistike te otkriti promjene koje nisu vidljive korištenjem samo jednog statističkog pristupa.

Materijali i metode: Eksperimentalni kompoziti dobiveni su miješanjem smole Bis-GMA / TEGDMA $s$ bioaktivnim staklom (BG) i inertnim punilima (barijevo staklo i silicijev dioksid) u centrifugalnoj miješalici. Inertna punila dodana su do ukupnog opterećenja punila od $70 \%$. Kontrolni kompozit sadrži samo inertna punila $(70 \%)$. Dva remineralizirajuća kompozita s masenim udjelom bioaktivnog stakla (BG) $10 \%$ ili $40 \%$ označena su kao bioaktivni-10 i bioaktivni-40. Dentinski supstrati pripremljeni su od intaktnih trećih kutnjaka, polirani pomoću papira silicijevog karbida P600 i ugrađeni u akrilatnu smolu. Adhezijska veza između kompozitnih cilindara (širina $=3 \mathrm{~mm}$, visina $=2 \mathrm{~mm}$ ) i dentina stvorena 
je pomoću dvokomponentnog samojetkajućeg adheziva (Clearfil SE Bond 2, Kuraray). Uzorci su skladišteni na $37^{\circ} \mathrm{C}$ u destiliranoj vodi i testirani u uređaju za mjerenje jačine adhezijske sveze (test smicanja) nakon 1 tjedna i 1 godine. Optimalni broj uzoraka za analizu pouzdanosti dobiven je pripremom $\mathrm{n}=20$ po eksperimentalnoj skupini (ukupno $\mathrm{n}=120$ za cijelo istraživanje).

Rezultati: Srednja snaga svezivanja mjerena nakon 1 tjedna i 1 godine bila je statistički slična za kontrolni kompozit (21,9 naspram 24,0 MPa) i za bioaktivni-10 (19,6 naspram 19,1 MPa). Međutim, Weibullova statistika otkrila je značajan pad pouzdanosti veze nakon starenja: Weibullovi moduli smanjili su se sa 13,5 na 3,9 za kontrolni kompozit i sa 12,3 na 3,8 za bioaktivni- 10 . Za bioaktivni- 40 , prosječna črrstoća veze značajno je pala nakon jedne godine $(8,1$ prema $6,8 \mathrm{MPa})$, ali njegova pouzdanost je ostala nepromijenjena, što je utvrđeno statistički sličnim Weibullovim modulima.

Zaključak: Pogoršanje snage svezivanja nakon jedne godine utvrđeno je korištenjem analize pouzdanosti kod kontrolnog i eksperimentalnog bioaktivnog kompozita iako konvencionalna statistika nije mogla razlikovati promjene prosječne snage svezivanja.

KLJUČNE RIJEČI: ortohantavirusi; virus Puumala; virus Dobrava; imunološki parametri; citokini

\section{INTRODUCTION}

Dental composite materials are mixtures of organic resins and inorganic filler particles interconnected by a coupling agent. The inorganic filler particles are coupled with silanes and scattered in a polymer matrix. Silane makes possible chemical bonding of fillers surfaces with the methacrylate network ${ }^{1}$. Compared to conventional, the experimental, bioactive composites contain unsilanized bioactive fillers which are unable to bond to the methacrylate network and thus can deteriorate mechanical properties².

Dental composites are bonded to dental hard tissues by using adhesive systems ${ }^{3}$. Bond strength testing can measure the capability of adhesive system which somewhat provides an indication of the permanence of a restoration ${ }^{4}$. The main characteristic of bond strength data is high variability ${ }^{5}$. Many factors can influence test results, for example test specimen properties, preparation of specimens, handling of materials, specimen storage, experimental setup design, and experimental technique. However, the fundamental source of variability is associated with the brittle nature of materials such as dental composites ${ }^{6}$. Maximum stress brittle materials can resist varies unpredictably from specimen to specimen even if a set of seemingly identical specimens are tested under the same conditions ${ }^{7}$. The fracture is hard to predict because there are no early warnings or visible deformation ${ }^{8}$. The strength of brittle materials is determined by pre-existing defects or flaws present in the specimen, rather than by inherent material properties. Therefore, the measured strength of brittle materials depends on the probability of occurrence of a critical defect in their structure?

In materials science, when measuring mechanical properties such as strength, it is normal practice to make a series of measurements on a number of apparently identical specimens ${ }^{6,10}$.
The most widely used method for reporting the results from such tests is to give the number of tests performed, the mean strength and the standard deviation ${ }^{11,12,13}$. This method assumes that the mean value is the "true value" and that data scattering around this true value is due to variations in test method or specimen preparation. When the fracture process is of brittle nature, the results show considerable variation, representing characteristics of tested specimens and not the material itself $(6,10)$. Hence, some authors suggest that it is more suitable to characterize brittle materials by means of the probability of failure at a certain stress level, which can be calculated from the Weibull distribution function 9 , 10, 14, 15 .

Weibull analysis is based on extreme value distributions and an empirically derived statistical distribution function that relate strength to the failure of the largest flaws ${ }^{16}$. Weibull's basic premise was "the weakest link theory" i.e. if the weakest part of the material fails, the entire sample fails. Weibull distribution can evaluate the probability of failure at a certain level of stress and vice versa ${ }^{8}$.

The objective of this in vitro study was to test shear bond strength of experimental composite resins and apply the statistical approach of reliability analysis (Weibull) in order to evaluate aging-related changes. Additionally, the conventional statistical approach (analysis of variance, ANOVA) was applied to the same bond strength data to compare its discriminative capability to that of Weibull analysis.

\section{MATERIALS AND METHODS}

Preparation of experimental composites

The photo-curable monomer system for experimental composites was prepared by blending a Bis-GMA/TEGDMA (60/40) resin with a photoinitiator system (camphorquinone/ tertiary 
Table 1. Composition of experimental composite materials

\begin{tabular}{|c|c|c|c|c|c|}
\hline \multirow{2}{*}{ Material code } & \multicolumn{2}{|c|}{ Filler composition (wt\%) } & \multirow{2}{*}{$\begin{array}{l}\text { Total filler ratio } \\
\text { (wt\%) }\end{array}$} & \multirow{2}{*}{ Resin composition } & \multirow{2}{*}{$\begin{array}{l}\text { Photoinitiator } \\
\text { system }\end{array}$} \\
\hline & Bioactive glass $4 \mathrm{~S} 5 \mathrm{~S}$ & $\begin{array}{l}\text { Reinforcing fillers (Ba- } \\
\text { glass+silica) }\end{array}$ & & & \\
\hline control composite & 0 & 70 & 70 & \multirow{3}{*}{$\begin{array}{c}\text { Bis-GMA } \\
\text { TEGMA }\end{array}$} & \multirow{3}{*}{$\begin{array}{c}\text { Camphorquinone } \\
\text { Ethyl-4 } \\
\text { (dimethylamino) } \\
\text { benzoate }\end{array}$} \\
\hline $\begin{array}{l}\text { bioactive-10 } \\
\text { composite }\end{array}$ & 10 & 60 & 70 & & \\
\hline $\begin{array}{l}\text { bioactive- } 40 \\
\text { composite }\end{array}$ & 40 & 30 & 70 & & \\
\hline
\end{tabular}

amine) in a magnetic stirrer for $48 \mathrm{~h}$. The obtained resin was mixed with variable amounts of reinforcing fillers (barium glass and silica) and bioactive glass 45S5 in an asymmetric centrifugal mixer (Speed Mixer TM DAC 150 FVZ, Hauschild \& Co. KG, Hamm, Germany) at $2700 \mathrm{rpm}$ during five minutes (Table 1). Two remineralizing composites with 10 or $40 \mathrm{wt} \%$ of BG were denoted as bioactive- 10 and bioactive- 40 . Inert fillers were added up to the total filler load of $70 \mathrm{wt} \%$. Control composite contained only inert fillers $(70 \mathrm{wt} \%)$. The experimental composite pastes were then kept for $12 \mathrm{~h}$ in vacuum to remove air inclusions.

\section{Specimen Preparation and Shear Bond Strength Testing}

Intact human third molars with completed root formation were collected after extraction and stored in $1 \%$ chloramine solution at room temperature. Dentin substrates for bonding were prepared using a low-speed saw (IsoMet 1000, Buehler; Lake Bluff, IL, USA) 2-4 months after extraction. The dentin slabs were embedded in a cold-curing methacrylate resin (Technovit 4004, Kulzer, Germany) using a 15-hole stainless steel mold (Ultradent Products, Inc., South Jordan, UT, USA), wet-polished using P600 silicon carbide paper and instantly used for the bonding procedure. Prior to application of the adhesive system, dentin surfaces were gently air-dried to remove any visible moisture. Bonding area was restricted using an adhesive tape with an aperture of $3 \mathrm{~mm}$ in diameter. On the flat dentin surface, a two-step self-etch bonding agent Clearfil SE Bond 2 (Kuraray Noritake; Tokyo, Japan, LOT:000031, EXP:2019-02) was applied according to the manufacturer's instruction: primer application with an applicator brush for $20 \mathrm{~s}$, mild air drying for $5 \mathrm{~s}$, applying bond and uniformly spreading the bond layer using a gentle air flow, followed by polymerization for $10 \mathrm{~s}$ from a distance of $1 \mathrm{~mm}$ (Bluphase Style, Ivoclar Vivadent; Schaan, Liechtenstein, Ser. No. 1120006563).

Using a polypropylene mold (Bonding Clamp and Bonding Mold Inserts, Ultradent Products, Inc., South Jordan, UT, USA) composite cylinders were prepared ( $\mathrm{d}=3 \mathrm{~mm}, \mathrm{~h}=2 \mathrm{~mm})$. Specimens were stored at $37^{\circ} \mathrm{C}$ in distilled water and fractured in shear mode by loading in bond strength testing machine Ultratester (Ultradent Products) after 1 week and 1 year. Testing was performed at a constant crosshead speed of $1 \mathrm{~mm} / \mathrm{min}$ until fracture. The optimal sample size for reliability analysis was obtained by preparing $n=20$ per experimental group ( 3 materials $\times 2$ aging times $\times 20$ specimens per group; total $n=120$ for the whole study).

\section{Statistical analysis}

The normality of distribution was evaluated using Shapiro-Wilk's test. The homogeneity of variances among experimental groups was verified using Levene's test. Mean values of bond strength were compared among different combinations of material and measurement time using one-way ANOVA. After identifying an overall statistically significant difference among groups, multiple post-hoc comparisons were performed using Tukey's adjustment.

\section{Weibull analysis}

Reliability analysis begins by ranking the samples according to calculated bond strength is how. The values which are plotted along the horizontal axis of a Weibull graph are obtained as natural logarithms of bond strength.

The probability of failure (Pf) for each specimen from a group of $\mathrm{n}$ specimens is given by the following expression:

$$
\mathrm{Pf}=(\mathrm{i}-0.5) / \mathrm{n}
$$

where $\mathrm{i}$ is the ranking number in ascending order of bond strength data (weakest rank 1, strongest rank $\mathrm{N}$ ) while $\mathrm{n}$ is the total number of specimens within the experimental group. On the vertical axis is plotted double natural logarithm of $[1 /(1-\nabla$ $\mathrm{Pf})] \mathrm{Q}$. Linear regression is then used to fit a linear function through the plotted data points. The slope of the obtained linear function represents Weibull modulus ${ }^{8}$.

\section{REsults}

Mean bond strengths measured after 1 week and 1 year were statistically similar for the control composite (21.9 vs. 24.0 $\mathrm{MPa}$ ) and for bioactive-10 (19.6 vs. 19.1 MPa) according to 


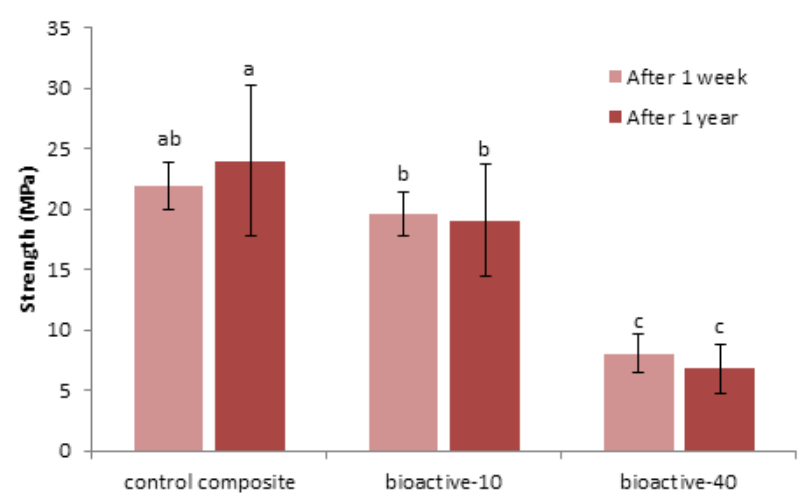

Figure 1. Average bond strength of experimental composites. Error bars represent \pm 1 s.d. Same letters denote statistically homogeneous groups.

conventional statistics (Figure 1). Concerning the other two tested materials, significantly lower bond strength was observed for the bioactive- 40 composite (Figure 1). For bioactive- 40 , mean bond strength declined significantly after 1 year (8.1 vs. $6.8 \mathrm{MPa})$.

The shape parameter (Weibull modulus) of the Weibull distribution is represented by the slope of the fit lines: steeper slope indicates higher reliability (Figures 2-4). In comparison to the previously mentioned results of the statistical analysis, Weibull statistics revealed a significant decline in bond reliability after aging: Weibull moduli decreased from 13.5 to 3.9 for the control composite (Figure 2) and from 12.3 to 3.8 for bioactive- 10 (Figure 3). For bioactive-40 composite, reliability remained unimpaired, as identified by statistically similar Weibull moduli (Figure 4).

\section{DISCUSSION}

This study was conducted based on the analysis of bond strength data by two different statistical methods. The arithmetic mean, which was used to describe the central tendency of bond strength within sample sets showed similar values for the control and bioactive- 10 experimental composites after one week and one year. However, Weibull analysis revealed a decline in reliability after 1 -year aging.

The Weibull three parameter equation, which links the probability of failure (Pf) to stress $(\mathbb{Q})$ is defined as:

$$
\mathrm{Pf}=1-\exp \left[-\left(\left(\mathbb{\nabla}-\bigotimes_{\mathrm{u}}\right) / \mathbb{\mathrm { Q }}_{\mathrm{o}}\right) \mathrm{m}\right]
$$

The constant $\bigotimes \mathrm{u}$ is the lowest level of stress at which Pf approaches zero and it is customary to assume that $\otimes \mathrm{u}=0$. In that case is obtained two-parameter Weibull distribution which is generally used to evaluate material reliability. $\mathbb{\Delta}$ stands for the measured strength. The scale parameter is $\nabla_{\mathrm{o}}$, defined as the uniform stress at which the probability of failure is $63.2 \%$ and intersection with the $\mathrm{x}$-axis gives the logarithm of the charac-

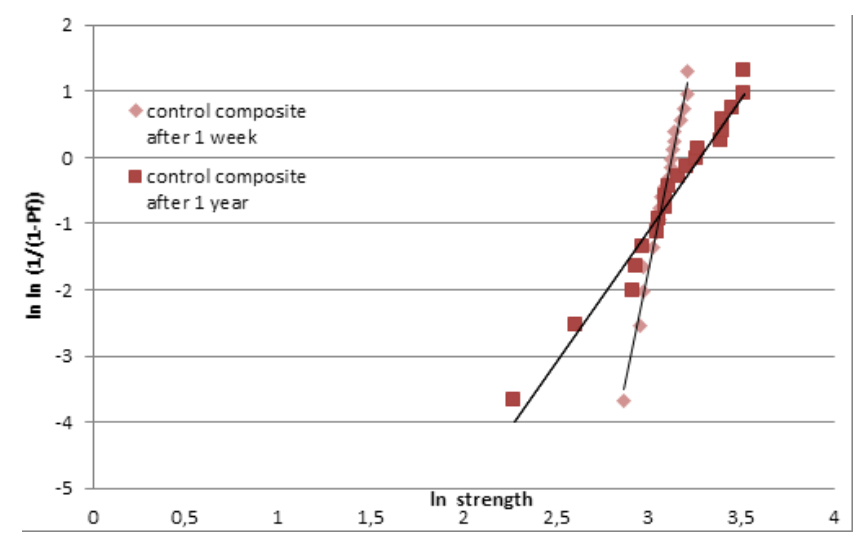

Figure 2. Weibull plots of the control composite

teristic strength. A decline in the scale parameter of Weibull distribution is represented by shifting of the fit lines toward lower values of x-axis i.e. shifts data to the left. Mean bond strength in the conventional analysis is analogous to the characteristic strength in Weibull analysis and both represent the scale parameter of their corresponding distributions ${ }^{8}$.

Mean strength marks altogether strength of the material, however, does not describe the relationship of each individual strength value and its corresponding probability of failure ${ }^{6}$. The important practical use has the constant $\mathrm{m}$, which represents the Weibull modulus ${ }^{8}$. In conventional statistics, the spread of data (standard deviation) is represented as an error of measurement, while in reliability analysis scatter of data is not an experimental error but it classified through Weibull modulus. Previously stated parameter provides a measure of material dependability with simple calculations and it is also known as a shape parameter (10). In that sense, Weibull modulus describes the form of the distribution. A high value of Weibull modulus (i.e. flaw sizes within a specimen are similar) indicates a close grouping of fracture stress values while a low value indicates a wide Weibull distribution is typical for a high spread of defects and less predictable bond strength.

Essentially, Weibull modulus is the parameter that makes a difference in interpretation of results compared with a conventional statistical approach using ANOVA. As seen in the results obtained, the mean strength is approximately the same at both measuring times, but the wide range indicates a higher spread of material defects and more unpredictable bond strength after one year.

In bioactive- 40 composite the decrease in mean bond strength and reliability was observed. It was expected because unsilanized bioactive fillers behaved as structural flaws ${ }^{17}$. Bioactive fillers cannot be silanized to avoid the interference of the silane layer with ion release. Due to the lack of surface silanization, bioactive fillers cannot participate in the distribution of forces 


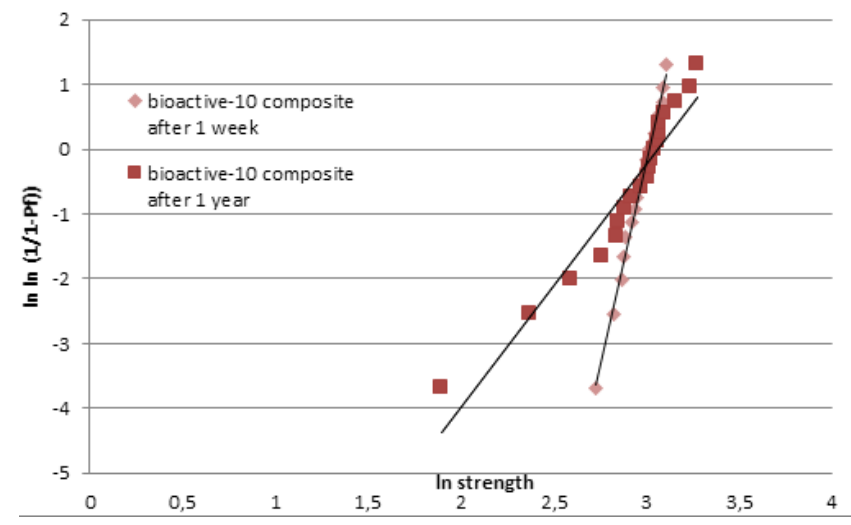

Figure 3. Average bond strength of experimental composites. Error bars represent \pm 1 s.d. Same letters denote statistically homogeneous groups.

between filler particles and the resin polymer matrix, which ultimately leads to impaired mechanical properties ${ }^{18}$. In order to facilitate water diffusion and the consequent release of ions, resin in bioactive composites is normally more hydrophilic than in conventional composites ${ }^{19}$. High hydrophilicity diminishes mechanical properties because of accelerated degradation of the composite structure $^{20}$. With regards to increase in reliability observed in bioactive- 40 composite (6.8 in regards to 3.9 for the control composite apropos 3.8 for bioactive-10) during aging some studies ascribe to the increase of plastic zone ahead of the crack and consequent lowering of material brittleness ${ }^{21,22}$. Bradna et al. compared various adhesive application protocols using reliability analysis. Shear bond strength was determined after $24 \mathrm{~h}$. One of the tested adhesives was Clearfil SE Bond with mean bond strength values ( \pm s.d.) of $22.8 \pm 3.6$ MPa while Weibull modulus amounted to 6.5. The adhesive was combined with microhybrid composite Opticor New $(\mathrm{d}=3.5 \mathrm{~mm}, \mathrm{~h}=2 \mathrm{~mm})^{9}$. In our study mean bond strength measured after 1 week for the control composite was 21.9 MPa. The results of this in vitro study are to some extent comparable to those from the study by Par et al. which investigated dentin bond strength during aging for 1 week, 1 month, 3 months, 6 months and 1 year. In that study it was concluded that enhanced BG amount diminished bond strength and reliability. Also, the bond strength reduction was linearly dependent on the amount of $\mathrm{BG}^{17}$.

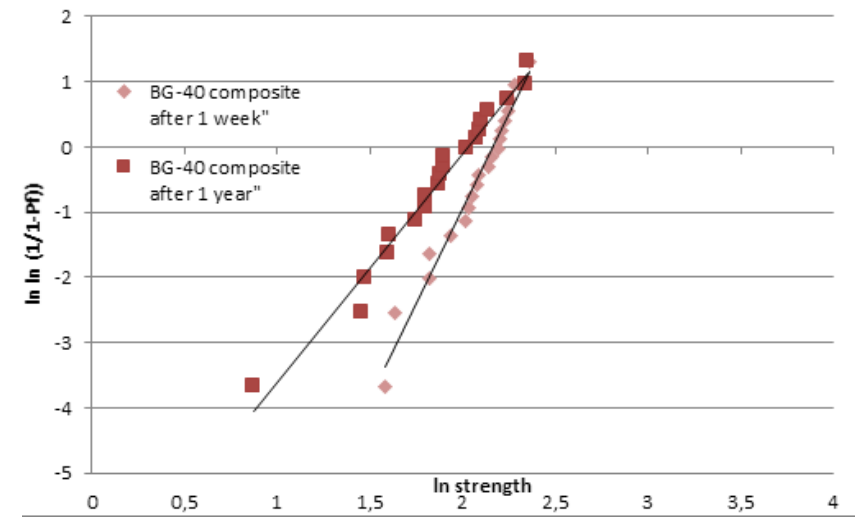

Figure 4. Weibull plots of the control composite

\section{CONCLUSSIONS}

With the limitations of this in vitro study, the following conclusions were drawn:

1. Although values of mean bond strength were similar after 1 week and 1 year, decreased Weibull moduli in the control composite and bioactive-10 after one year are indicative of decline in material's reliability and deterioration of bond strength. 2. A decrease in bond strength was observed with an increasing amount of bioactive glass. It is explained by the presence of unsilanized particles which acted as structural flaws.

\section{ACKNOWLEDGMENTS}

This study has been presented as poster presentation at the 9th CONSEURO Meeting in Berlin, Germany, held June 14-15, 2019. 


\section{LITERATURE:}

1. Antonucci JM, Dickens SH, Fowler BO, Xu HH, McDonough WG. Chemistry of Silanes: Interfaces in Dental Polymers and Composites. J Res Natl Inst Stand Technol. 2005;110(5):541-58.

2. Par M, Španović N, Bjelovučić R, Marović D, Schmalz G, Gamulin $\mathrm{O}$, Tarle Z. Long-term water sorption and solubility of experimental bioactive composites based on amorphous calcium phosphate and bioactive glass. Dental Materials Journal. 2019; 38 (4):555-564. 3. Puckett AD, Fitchie JG, Kirk PC, Gamblin J. Direct composite restorative materials. Dent Clin North Am. 2007;51(3):659-75. 4. Sirisha K, Rambabu T, Shankar YR, Ravikumar P. Validity of bond strength tests: a critical review: part I. J Conserv Dent. 2014;17:305-11.

5. Heintze S, Rousson V, Mahn E. Bond strength tests of dental adhesive systems and their correlation with clinical results - A meta-analysis. Dent Mater. 2015;31:423-434.

6. Burrow MF, Thomas D, Swain MV, Tyas MJ. Analysis of tensile bond strength using weibull statistics. Biomaterials. 2004;25:50315035 .

7. Lu, C.S.; Danzer, R.; Fischer, F.D. Fracture statistics of brittle materials: Weibull or normal distribution. Phys Rev. E 2002;65:1-4. 8. Quinn JB, Quinn GD. A practical and systematic review of Weibull statistics for reporting strengths of dental materials. Dent Mater. 2010; 26:135-147.

9. Bradna P, Vrbova R, Dudek M, Roubickova A, Housova D. Comparison of bonding performance of self-etching and etchand-rinse adhesives on human dentin using reliability analysis. J Adhes Dent. 2008;10(6):423-429.

10. McCabe JF,Carrick TE. A statistical approach to the mechanical testing of dental materials. Dent Mater. 1986;2:139-142.

11. Pecora N, Yaman P, Dennison J, Herrero A. Comparison of shear bond strength relative to two testing devices. J Prosthet Dent. 2002;88:511-515.
12. Luhrs AK, Guhr S, Schilke R, Borchers L, Geurtsen W, Gunay $\mathrm{H}$. Shear bond strength of self-etch adhesives to enamel with additional phosphoric acid etching. Oper Dent. 2008;33:155-162. 13. Placido E, Meira JB, Lima RG, Muench A, de Souza RM, Ballester RY. Shear versus micro-shear bond strength test: a finite element stress analysis. Dent Mater. 2007;23:1086-1092.

14. Sirisha, K.; Rambabu, T.; Ravishankar, Y.; Ravikumar, P. Validity of bond strength tests: A critical review-Part II. J. Conserv Dent. 2014;17:420-426.

15. Scherrer SS, Cesar PF, Swain MV. Direct comparison of the bond strength results of the different test methods: A critical literature review. Dent Mater.2010;26:e78-93.

16. Jayatilaka ADS, Trustrum K. Statistical approach to brittle fracture. J Mater Sci. 1977;12:1426-30.

17. Par M, Tarle Z, Hickel R, Ilie N. Dentin bond strength of experimental composites containing bioactive glass: changes during aging for up to 1 year. J Adhes Dent. 2018; 20:325-334.

18. Oral O, Lassila LV, Kumbuloglu O, et al. Bioactive glass particulate filler composite: Effect of coupling of fillers and filler loading on some physical properties. Dent Mater. 2014;30(5):570-7.

19. O’Donnell JN, Langhorst SE, Fow MD, Antonucci JM, Skrtic D. Light-cured dimethacrylate-based resins and their composites: comparative study of mechanical strength, water sorption and ion release. J Bioact Compat Polym. 2008; 23:207-226.

20. Ferracane JL. Hygroscopic and hydrolytic effects in dental polymer networks. Dent Mater.2006; 22:211-222.

21. Takeshige F, Kawakami Y, Hayashi M, Ebisu S. Fatigue behavior of resin composites in aqueous environments. Dent Mater. 2007;23(7):893-899.

22. Drummond JL. Degradation, fatigue, and failure of resin dental composite materials. J Dent Res. 2008;87(8):710-719. 